\title{
Eco-pharmacology: awareness and practice of drug disposal among medical students
}

\author{
Manjunath G. Narasimhaiah ${ }^{1 *}$, Aathira James ${ }^{1}$, Riyaj A. Kalaburgi ${ }^{2}$
}

${ }^{1}$ Department of Pharmacology, ${ }^{2}$ Department of Community Medicine, Sri Siddhartha Medical College, Tumkur, Karnataka, India

Received: 29 April 2020

Accepted: 06 June 2020

\section{*Correspondence:}

Dr. Manjunath G. Narasimhaiah,

Email: manjunatharmacology@gmail.com

Copyright: $@$ the author(s), publisher and licensee Medip Academy. This is an open-access article distributed under the terms of the Creative Commons Attribution Non-Commercial License, which permits unrestricted non-commercial use, distribution, and reproduction in any medium, provided the original work is properly cited.

\begin{abstract}
Background: Drugs are procured by the consumers from different sources. But most of the time it is in excess of the requirement, or not consumed completely. These unused drugs are disposed in a wrong manner which can lead to harmful effects on the environment. This study was to check the knowledge and practice by medical students.

Methods: It was cross sectional observational study involving different batches of medical students by giving a semistructured questionnaire.

Results: A total of 165 participants (72 males, 93 females) from different batches of MBBS, predominantly 1 st and 2nd year. Majority of them are aware of the term eco-pharmacology 70 (91\%) and environmental effects 86 (06\%).

The most common mode of procurement is with prescription and possesses more than $50 \%$ of the expired drugs. Throwing back into the dustbin was the mode of disposal.

Conclusions: There is poor knowledge of drug disposal behaviour. Sufficient training should be given to the medical students to protect the ecosystem.
\end{abstract}

Keywords: Eco-pharmacology, Medical students, Hazards, Environment

\section{INTRODUCTION}

Eco-pharmacology is a new concept and an emerging science which deals with the pharmaceuticals in environment (PIE) and the adverse impact of the pharmaceutical active ingredients on the environment. ${ }^{1}$ Pharmaceuticals and personal care products include thousands of chemicals that make up fragrances, cosmetics and veterinary medicines but a category of drugs known as 'over the counter drugs' are also included in this list. ${ }^{2}$

Studies have shown that households either threw the materials in the garbage or rinsed them down the toilet or sink. Over $7 \%$ did not dispose their unused medications, creating a household stockpile that may lead to accidental or deliberate wrongful ingestions. ${ }^{3,4}$

Drugs are usually water soluble and therefore find their way into the sewage. This has added an altogether new dimension of ecopharmacology. ${ }^{5}$ Pharmaceutical ingredients are excreted either as parent compound or metabolites from patient into the environment which can enter food chains and concentrate as they move upward into larger predators. ${ }^{4,6}$

Self-medication practices are more prevalent in India approximating $53.57 \%$ with NSAID's and anti-allergic drugs most frequently utilized for headache and cold. ${ }^{7}$ In addition, in a country like India which has no particular definition for over the counter drugs in its laws, the control on drugs that can be bought by the common man 
is very sparse. Even antibiotics can be bought without a prescription. $^{3}$

Awareness about drug disposal and its effects among the medical students is less researched. Hence there is a serious need for more comprehensive studies and programmes to educate the masses on proper methods of drug disposal

\section{Objective}

To analyze the awareness among medical students across different stages of medical education on ecopharmacology and disposal practices.

\section{METHODS}

This was a cross sectional questionnaire-based study conducted at Sri Siddhartha Medical College, Tumkur after obtaining prior approval from the ethics committee during the period from February to April 2020.

The participants are medical students from different phases were enrolled into the study after taking informed consent. A semi-structured questionnaire was developed after reviewing the literature to assess the subjects' knowledge about eco pharmacology and drug disposal methods. It consists of demography as part A and knowledge questions in part B. Only completed questionnaire were used for analysis. The data obtained were entered in Microsoft excel and analyzed using statistical software. The results are given in descriptive statistics.

\section{RESULTS}

A total of 165 participants belonging to different phases of MBBS responded to the questionnaire with majority from $1^{\text {st }}$ and $2^{\text {nd }}$ phase $89.09 \%$. Males were 72 with mean age of $19.85 \pm 1.57$ and females were 93 with a mean age of $19.81 \pm 1.15$ (Table 1$)$.

Table 1: Distribution of participants by age and batch of MBBS.

\begin{tabular}{|llll|}
\hline Variables & \multicolumn{1}{c|}{ Male } & Female & Total \\
\hline \multicolumn{1}{|l}{ Age (in years) } & $\mathbf{N}(\%)$ & $\mathbf{N}(\%)$ \\
\hline $18-26$ & $72(43.6)$ & $93(56.3)$ & $165(100)$ \\
\hline Year of study & & \\
\hline $1^{\text {st }}$ MBBS & $29(40.28)$ & $42(45.16)$ & $71(43.03)$ \\
\hline $2^{\text {nd }}$ MBBS & $37(51.39)$ & $39(41.94)$ & $76(46.06)$ \\
\hline $\begin{array}{l}3^{\text {rd }} 4^{\text {th }} \text { and } \\
\text { intern }\end{array}$ & $6(8.33)$ & $12(12.90)$ & $18(10.90)$ \\
\hline
\end{tabular}

Among them 117 (70.91\%) were aware of the term ecopharmacology which they are aware from the school level (24.79\%), college (18.8\%), MBBS (54.70\%) and others (1\%). Majority of them were aware of the environmental effects $(n=136,86.06 \%)$. Respondent's awareness regarding the effect on the environment is shown in (Figure 1).

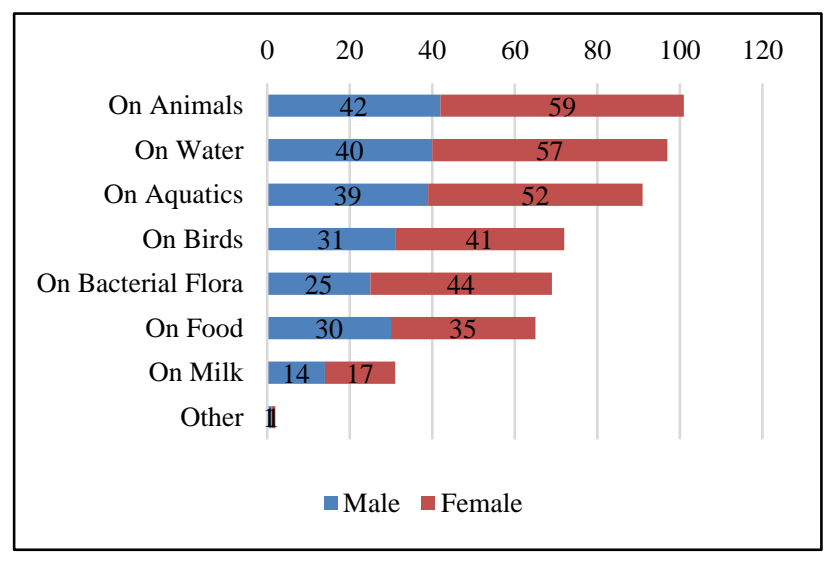

Figure 1: Participants awareness of improper drug disposal on environment.

Figure 2 expresses the knowledge of the participants' regarding different methods of disposal of unused drugs.

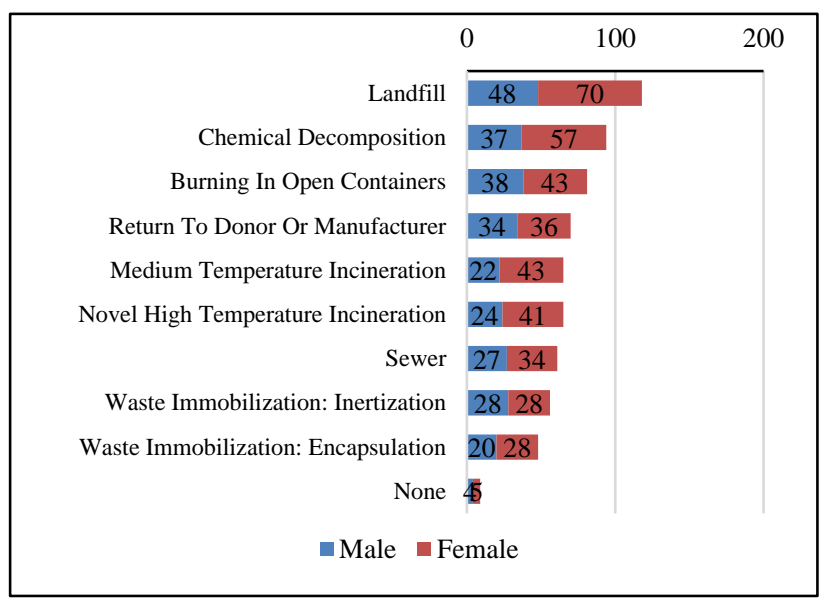

Figure 2: Participants awareness on different methods of drug disposal.

The drugs which are available with the respondents were mainly obtained through prescription from the pharmacy $(n=155,48.7 \%)$ and the least was through online purchase $(n=28,8.8 \%)$. Most of the drugs which were available with them mainly belonged to antibiotics $(n=122,18.15 \%)$, analgesics $(n=136,20.24 \%)$ and antipyretics $(n=120,17.86 \%)$ (Table 2$)$.

The number participants responded that purchased drugs were used only in $41(24.85 \%)$ and had unused drugs up to 10 with them $(n=102,82.25 \%)$, out of which $54 \%$ of them were expired. Sadly, it was found that majority of them $82.42 \%$ threw them into dustbin for open disposal and just $13.33 \%$ returned back to pharmacy. They were not aware of classifying before its disposal (Table 3 ). The striking response was that they want to introduce this as a part of MBBS curriculum. 
Table 2: Different types of drugs procured and available.

\begin{tabular}{|llll|}
\hline \multirow{2}{*}{ Type of drugs } & Male & Female & Total \\
\hline Antibiotics & $\mathbf{N}(\boldsymbol{\%})$ & $\mathbf{N}(\boldsymbol{\%})$ & $\mathbf{N}(\boldsymbol{\%})$ \\
\hline Anti-pyretic & $55(18.46)$ & $67(17.91)$ & $122(18.15)$ \\
\hline Analgesics & $57(19.13)$ & $79(21.12)$ & $136(20.24)$ \\
\hline Anti-inflammatory & $50(16.78)$ & $70(18.72)$ & $120(17.86)$ \\
\hline Anti-histamine & $33(11.07)$ & $38(10.16)$ & $71(10.57)$ \\
\hline Anti-diarrheal & $34(11.41)$ & $29(7.75)$ & $63(9.38)$ \\
\hline Antiemetics (for vomiting) & $34(11.41)$ & $44(11.76)$ & $78(11.61)$ \\
\hline Other & $34(11.41)$ & $45(12.03)$ & $79(11.76)$ \\
\hline Total & $1(0.34)$ & $2(0.53)$ & $3(0.45)$ \\
\hline
\end{tabular}

*This is a multiple response question. Total count will exceed total cases.

Table 3: Participants practice pattern of unused drug disposal.

\begin{tabular}{|c|c|c|c|c|}
\hline \multirow{2}{*}{ Question } & \multirow{2}{*}{ Response } & Male & Female & Total \\
\hline & & $\mathbf{N}(\%)$ & $\mathbf{N}(\%)$ & $\mathbf{N}(\%)$ \\
\hline \multirow{3}{*}{ Did you use all the purchased drugs } & Yes & $21(29.17)$ & $20(21.51)$ & $41(24.85)$ \\
\hline & No & $51(70.83)$ & $73(78.49)$ & $124(75.15)$ \\
\hline & Total & $72(100.00)$ & $93(100.00)$ & $165(100.00)$ \\
\hline \multirow{5}{*}{$\begin{array}{l}\text { If no, how many unused drugs do } \\
\text { you have at home? }\end{array}$} & $0-5$ & $26(50.98)$ & $35(47.95)$ & $61(49.19)$ \\
\hline & $5-10$ & $15(29.41)$ & $26(35.62)$ & $41(33.06)$ \\
\hline & $10-15$ & $3(5.88)$ & $6(8.22)$ & $9(7.26)$ \\
\hline & 15 or more & $7(13.73)$ & $6(8.22)$ & $13(10.48)$ \\
\hline & Total & $51(100.00)$ & $73(100.00)$ & $124(100.00)$ \\
\hline \multirow{6}{*}{$\begin{array}{l}\text { In this, how many of these drugs are } \\
\text { expired? }\end{array}$} & $0-5$ & $22(43.14)$ & $43(58.90)$ & $65(52.42)$ \\
\hline & $5-10$ & $2(3.92)$ & $0(0.00)$ & $2(1.61)$ \\
\hline & $10-15$ & $0(0.00)$ & $1(1.37)$ & $1(0.81)$ \\
\hline & 15 or more & $1(1.96)$ & $1(1.37)$ & $2(1.61)$ \\
\hline & $\begin{array}{l}\text { Don't know/have not } \\
\text { checked }\end{array}$ & $26(50.98)$ & $28(38.36)$ & $54(43.55)$ \\
\hline & Total & $51(100.00)$ & $73(100.00)$ & $124(100.00)$ \\
\hline \multirow{5}{*}{$\begin{array}{l}\text { How do you dispose of the drugs at } \\
\text { home? }\end{array}$} & Throw in dustbin & $56(77.78)$ & $80(86.02)$ & $136(82.42)$ \\
\hline & Flush down toilet & $1(1.39)$ & $3(3.23)$ & $4(2.42)$ \\
\hline & Return to pharmacy & $14(19.44)$ & $8(8.60)$ & $22(13.33)$ \\
\hline & Other & $1(1.39)$ & $2(2.15)$ & $3(1.82)$ \\
\hline & Total & $72(100.00)$ & $93(100.00)$ & $165(100.00)$ \\
\hline \multirow{3}{*}{$\begin{array}{l}\text { Do you classify the different types of } \\
\text { drugs that you own before disposal? }\end{array}$} & Yes & $29(40.28)$ & $25(26.88)$ & $54(32.73)$ \\
\hline & No & $43(59.72)$ & $68(73.12)$ & $111(67.27)$ \\
\hline & Total & $72(100.00)$ & $93(100.00)$ & $165(100.00)$ \\
\hline
\end{tabular}

\section{DISCUSSION}

In our study almost $71 \%$ of the participants were aware of eco-pharmacology which they have been learnt over a period from school to medical college including their hazards on environment. These pharmaceutical ingredients are excreted either as parent compound or metabolites from patient into the environment which can enter food chains and concentrate as they move upward into larger predators. ${ }^{4,6}$

Improper disposal of unused drugs can affect almost all the creatures leading to water contamination, damage to animals, aquatics, birds and intestinal flora. Food chain is also affected with contamination of milk. Several studies have already showed the effects on aquatic and amphibian wild life, multi drug resistance and vultures. $^{4,8,9}$

Most of the drugs which were available with them were obtained with prescription from the pharmacist only similar to study conducted by Shubha et al whereas there was some amount of drugs purchased online too. ${ }^{5}$ Among them analgesics, antipyretics and antibiotics were the most frequently used drugs which are also the common group of drugs consumed by the people of US. ${ }^{5,10,11}$

Only one quarter of the purchased drugs were used. And nearly $83 \%$ of them had upto 10 unused drugs with half 
of the bulk being expired. The respondents were poorly aware of the method of disposal and classifying before being disposed in the landfill. This is persistently seen in previous studies also and has not brought any change in the system of education. ${ }^{5,12,13}$ Only a small percentage of participants opined of giving it to pharmacy back.

Though a number of regulatory bodies like the FDA and the European union have set some cut-off limit for environmental concentration of drugs, no actual testing is conducted after a drug is marketed to see if the environmental concentration was estimated correctly. ${ }^{5}$

Introduction of this awareness regarding drug disposal into the present curriculum can bring about a big change. Eco-pharmacovigilance can be introduced in the new CBME curriculum being rolled out by Medical Council of India

\section{CONCLUSION}

To conclude, medical students are aware of ecopharmacology and the damages it can do to the ecosystem. Inspite of previous studies also showing the same pattern, nothing much has been done. Adequate training by introducing this as a part of curriculum can bring an expected change.

\section{ACKNOWLEDGEMENTS}

We would like to thank MBBS students of Sri Siddhartha Medical college, Tumkur.

Funding: No funding sources

Conflict of interest: None declared

Ethical approval: The study was approved by the Institutional Ethics Committee

\section{REFERENCES}

1. Sreekanth TR, J Pharmacovigilance; 2014:2(5). Available at https://www.longdom.org/proceedings/ ecopharmacology-overview-15716/html. Accessed on 4 December 2019.

2. Illinois Sustainable Technology Center. Pharmaceuticals and Personal Care Products (PPCPs) in the Environment. Available at https://www.
istc.illinois.edu/research/pollutants/PPCPs_in_the_en vironment. Accessed on 4 December 2019.

3. Bhati I, Dhawan NG, Maheshwari RK. Greener Route to Prevent Pharmaceutical Pollution. Int J Pharmaceutical Chemical Sci. 2013;2(4):2277-5005.

4. Gautam V, Sahni YP, Jain SK, Shrivastav A. Ecopharmacovigilance: an environment safety issue. Pharma Innovation J. 2018;7(5):234-9.

5. Shubha P, Gramle A, Reddy S. Drug Disposing Behavior and Awareness of the Concept of Ecopharmacovigilance Among the Medical Faculty. Int J Basic Clin Pharmacol. 2017;6(5):1142-5.

6. Rahman SZ, Khan RA, Gupta V, Uddin M. Pharmacoenvironmentology: a component of pharmacovigilance. Environmental Health. 2007;6(20):1-3.

7. Rashid M, Chhabra M, Kashyap A, Undela K, Gudi SK. Prevalence and Predictors of Self-Medication Practices in India: A Systematic Literature Review and Meta-Analysis. Current Clin Pharmacol. 2019; $14: 1$.

8. Prakash V, Green RE, Pain DE, Ranade SP, Saravanan S, Prakash N, et al. Recent changes in populations of resident Gyps vultures in India. J Bombay Natural History Society. 2007;104:129-35.

9. Agnesh, Valluri. Eco-pharmacology: In the Offing. Int J Scientific Res Publications. 2016;6(1):22503153.

10. Wise R. Anti-microbial resistance: Priorities of action. J Antimicrob Chemother. 2002;49:585-6.

11. Green G. Understanding NSAIDs: from aspirin to COX-2. Clin Cornerstone. 2001;3:50-60.

12. Aditya S. Safe medication disposal: Need to sensitize undergraduate students. Int $\mathbf{J}$ Pharm Life Sci. 2013;4:2475-80.

13. Sasu S, Kummerer K, Kranert M. Assessment of pharmaceutical waste management at selected hospitals and homes in Ghana. Waste Manag Res. 2012;30:625-30.

Cite this article as: Narasimhaiah MG, James A, Kalaburgi RA. Eco-pharmacology: awareness and practice of drug disposal among medical students. Int J Basic Clin Pharmacol 2020;9:1007-10. 